\author{
HANNA NIEZNAŃSKA \\ Zakład Biochemii \\ Instytut Biologii Doświadczalnej im. M. Nenckiego PAN \\ Pasteura 3, 02-973 Warszawa \\ E-mail: h.nieznanska@nencki.gov.pl
}

\title{
ODDZIAŁYWANIE BIAŁKA PRIONOWEGO Z MIKROTUBULAMI
}

\section{WSTEP}

Zaburzenia struktury i funkcji cytoszkieletu, a w szczególności tej jego części, która zbudowana jest $z$ mikrotubul (nazywanej również cytoszkieletem mikrotubularnym), obserwowane sa w szeregu chorób neurodegeneracyjnych, w tym w pasażowalnych encefalopatiach gabczastych (ang. transmissible spongiform encephalopathies, TSE), znanych również jako choroby prionowe. Badania przeprowadzone w ciagu ostatnich lat sugeruja, że procesy neurodegeneracyjne, zachodzace w niektórych chorobach prionowych, moga być wynikiem bezpośredniego oddziaływania białka prionowego $z$ tubuliną.

\section{TUBULINA}

Cytoszkielet mikrotubularny pełni kluczowa rolę w licznych procesach komórkowych, takich jak transport organelli i makromolekuł, segregacja chromosomów, podział komórki, procesy wydzielnicze, różnicowanie i ruch komórek, a także determinacja morfologii i polarności komórki (NoGALES 2000). Głównym składnikiem cytoszkieletu mikrotubularnego sa spolimeryzowane heterodimery złożone $z$ a- i $\beta$-tubuliny, o masie czasteczkowej, odpowiednio, 55 i $53 \mathrm{kDa}$ (NoGALES 2000). Łańcuchy dimerów tubuliny tworza protofilamenty, które ułożone równolegle formuja cylindryczna strukture zwana mikrotubula (MT) (Ryc. 1A). Ilość protofilamentów w mikrotubuli może się wahać od 9 do 16, chociaż zazwyczaj wynosi 13 , co daje zewnętrzną średnicę $25 \mathrm{~nm}$, a wewnętrzna $\sim 17$ nm (WADE 2009, HAWKINS i współaut.
2010, BREuss i współaut. 2017). MT jest struktura biegunowa, gdyż wszystkie dimery ułożone sa w tym samym kierunku. Koniec MT, na którym znajduje się $\beta$-tubulina, jest nazywany końcem plus, szybko rosnacym, natomiast biegun zakończony a-tubulina jest nazywany końcem minus, wolno rosnacym. To właśnie sieć mikrotubul tworzy w komórce cytoszkielet mikrotubularny.

U człowieka zidentyfikowano co najmniej osiem izoform a-tubuliny i siedem $\beta$-tubuliny (LUDUEÑA 2013). Izoformy te kodowane sa przez różne geny i charakteryzują się zróżnicowaną ekspresja tkankowa oraz pojawiaja się na różnych etapach rozwoju organizmu (PARKER i współaut. 2017). Między poszczególnymi izoformami występuje duża homologia strukturalna w obrębie domeny na końcu aminowym (N-końcu), jak i środkowej. Domena na końcu karboksylowym (C-końcu) jest najmniej konserwowana, a jej nieustrukturyzowany końcowy fragment, złożony $z$ 18-24 reszt aminokwasowych jest miejscem licznych modyfikacji potranslacyjnych, takich jak np.: detyrozynacja, acetylacja, glutamylacja, glicylacja, fosforylacja (patrz WŁOGA oraz KLISZCZ i KASPRZAK $\mathrm{w}$ tym zeszycie KOSMOSU; WESTERMANN i WEBER 2003, JANKE 2014, BREUSS i współaut. 2017). Fragment ten zaangażowany jest $\mathrm{w}$ oddziaływania $\mathrm{z}$ wieloma innymi białkami (MACCIONI i współaut. 1988, CROSS i współaut. 1991, MELKI i współaut. 1991, JOURDAIN i współaut. 1997, AL-BASSAM 2002, WADE 2009) (opisano w dalszej części artykułu).

Model struktury przestrzennej heterodimeru tubuliny został opracowany przy wykorzystaniu krystalografii elektronowej (Ryc.

Słowa kluczowe: białko prionowe, choroby prionowe, mikrotubule, tubulina 
1 B) (Nogales i współaut. 1998, Downing i NoGAlES 1998, Lowe i współaut. 2001). Oba białka wykazują wysoki stopień homologii struktury III-rzędowej, przy $40 \%$ homologii struktury I-rzędowej. Domena N-końcowa zbudowana jest $z$ sześciu równoległych harmonijek $\beta$ połaczonych helisami a. W domenie tej znajduje się kieszeń wiażąca GTP w tzw. miejscu „N” a-tubuliny (ang. non-exchangeable) oraz wiążaca GTP/GDP w miejscu „E” $\beta$-tubuliny (ang. exchangeable) (DOWNING i NogAles 1998). GTP związany $z$ $\beta$-tubulina jest hydrolizowany do GDP, natomiast nukleotyd zwiazany $z$ a-tubulina nie ulega hydrolizie. Środkowy region tworza cztery harmonijki $\beta$ oraz trzy helisy a. W tym rejonie cząsteczki znajduje się też miejsce wiazania małych czasteczek regulacyjnych, np. taksolu. C-końcowa domenę tworza dwie antyrównoległe helisy usytuowane na zewnętrznej powierzchni mikrotubuli. $\mathrm{Na}$ modelu krystalograficznym nie widać ostatnich 10 reszt aminokwasowych a-tubuliny $i$ 18 reszt $\beta$-tubuliny, ze względu na wysoki stopień nieustrukturyzowania tych sekwencji.

Mikrotubule sa dynamicznymi strukturami, które moga ulegać rozpadowi i odbudowie (depolimeryzacji mikrotubul i polimeryzacji tubuliny). Ta właściwość tubuliny, nazywana dynamiczna niestabilnością, jest kluczowa dla wielu pełnionych przez nia funkcji (WADE 2009). Stabilność mikrotubul jest regulowana przez liczna grupe białek zwiazanych $\mathrm{z}$ mikrotubulami (ang. mikrotubule associated proteins, MAP) (SCHOENFELD i OBAR 1994, CASSIMERIS i SPITTLE 2001, AKHMANOVA i STEINMETZ 2008). Do grupy tej zaliczamy klasyczne lub tzw. strukturalne MAP (np.: MAP1, MAP2, MAP3, MAP4, MAPT) oraz białka pełniace inne funkcje, takie jak: motory molekularne (kinezyny, dyneiny), białka śledzace koniec plus mikrotubuli (np.: CLIP-170, CLIP-115, EB1, EB2) oraz białka zwiazane $z$ centrosomami. $Z$ punktu widzenia niniejszego artykułu najistotniejsze sa klasyczne MAP, do których zaliczamy MAP2 oraz MAPT, czyli białko Tau (ang. tubulin associated unit). Oba białka syntetyzowane są w neuronach, ale różnia się lokalizacją wewnątrzkomórkowa, MAP2 dominuje w dendrytach i ciele komórki nerwowej, zaś Tau w aksonie (RAMKUMAR i współaut. 2017). Białka te oddziałuja $z$ tubulina zazwyczaj w obrębie ujemnie naładowanych C-końcowych domen a- i $\beta$-tubuliny, zlokalizowanych, tak jak już wspomniano, na powierzchni mikrotubul. Oddziaływanie to jest regulowane przez modyfikacje potranslacyjne MAP, głównie przez fosforylację reszt seryny/treoniny (CASSIMERIS i SPITTLE 2001). Zwiększenie poziomu ufosforylowania MAP
A Heterodimer
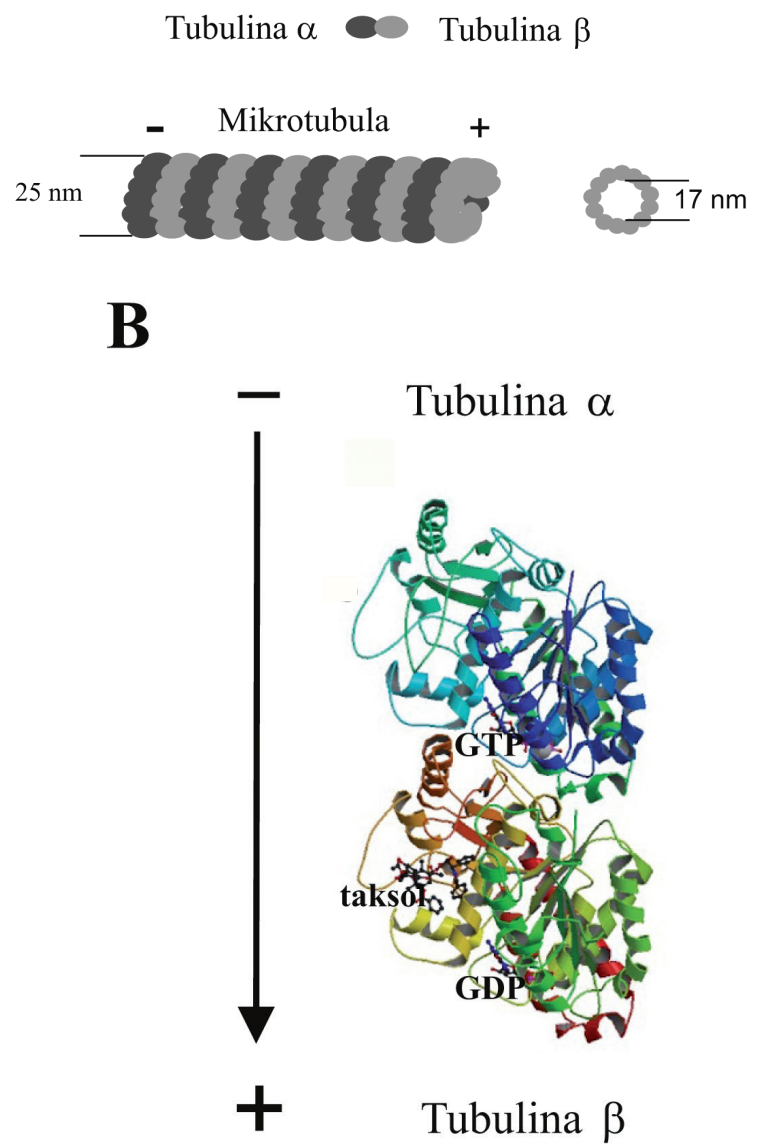

Ryc. 1. Budowa tubuliny i mikrotubul.

(A) Schemat przedstawiajacy heterodimer tubuliny oraz mikrotubule. Na rycinie zaznaczono koniec szybko rosnący $(+)$ i wolno rosnacy (-) MT. (B) Model struktury przestrzennej heterodimeru a- i $\beta$-tubuliny, otrzymany $w$ kompleksie $z$ taksolem. Na rycinie zaznaczono miejsca wiązania nukleotydów (GTP i GDP) oraz taksolu. Nieustrukturyzowane C-końcowe fragmenty, nie sa widoczne w strukturze krystalograficznej (wg PDB 10.2210/ pdb1TUB/pdb, NoGALES i współaut. 1998, zmodyfikowana).

zmniejsza ich powinowactwo do tubuliny, co z kolei obniża stabilność mikrotubul i wpływa na dynamikę tych struktur (DRECHSEL i współaut. 1992, BIERNAT i współaut. 1993, BRAMBLETT i współaut. 1993). Najlepiej poznaną kinaza fosforylująca zarówno MAP2, jak i Tau jest kinaza 3 syntazy glikogenu, GSK-3. Białka te moga być również fosforylowane przez wiele innych kinaz np.: kinazę białkowa $A$ (PKA), kinazę białkowa $C$ (PKC), kinazę białkowa zależna od $\mathrm{Ca}^{2+} \mathrm{i}$ kalmoduliny (CaMKII). W warunkach fizjologicznych modulacja poziomu ufosforylowania MAP stanowi precyzyjny mechanizm regulujacy dynamike cytoszkieletu MT. Natomiast $\mathrm{w}$ warunkach patologicznych np. w chorobie Alzheimera (AD - Alzheimer's disease), 


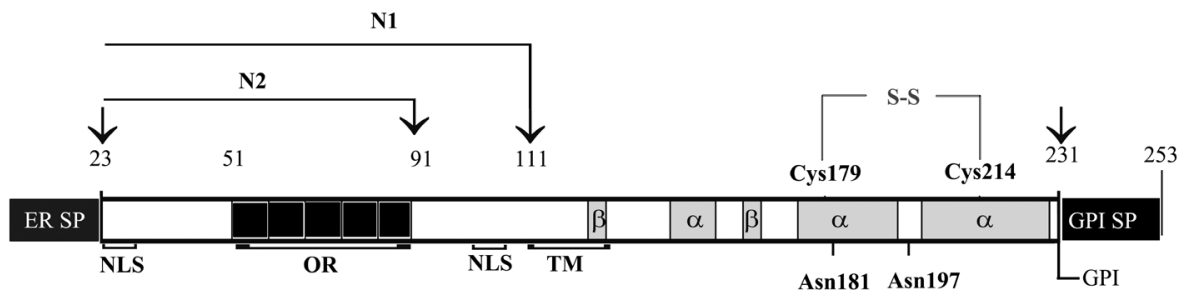

dochodzi do hiperfosforylacji białka Tau, co prowadzi do jego agregacji i w konsekwencji utraty wspomnianej stabilizujacej funkcji (ŚIMIĆ i współaut. 2016). Co ciekawe, podwyższony poziom ufosforylowania Tau obserwowany jest także w chorobach prionowych (SIKORSKA i współaut. 2009). Hiperfosforylacja Tau, jak i MAP2 opisywana jest również dla modeli doświadczalnych tych chorób (PEREZ i współaut. 2003, BAUTista i współaut. 2006).

Poza białkami stabilizujacymi strukture MT, znanych jest szereg białek ja destabilizujacych, takich jak katanina, spastyna czy fidżetyna, oraz uniemożliwiających formowanie mikrotubul poprzez sekwestrację heterodimerów tubuliny, jak statmina (JOURDAIN i współaut. 1997, ZHANG i współaut. 2007). Co ciekawe, od niedawna, do puli białek destabilizujących mikrotubule możemy zaliczyć również białko prionowe.

\section{BIAŁKO PRIONOWE}

Białko prionowe (ang. prion protein, PrP) jest glikoproteina $u$ ssaków wysoce zachowana w toku ewolucji. Ponadto, homologi białka prionowego zidentyfikowano $\mathrm{w}$ organizmach przedstawicieli wielu gromad kręgowców (PREMZl i współaut. 2004, Rivera-Milla i współaut. 2006). Białko to ulega ekspresji w wielu różnych tkankach i narzadach np.: $\mathrm{w}$ mięśniach szkieletowych, mięśniu sercowym, nerkach, trzustce, płucach, ale w najwyższym stężeniu występuje w komórkach ośrodkowego i obwodowego układu nerwowego (BENDHEIM i współaut. 1992). PrP jest polipeptydem składajacym się z 253 aminokwasów (u człowieka) (Ryc. 2). Na końcach aminowym i karboksylowym czasteczki, białko to posiada sekwencje sygnałowe (reszty aminokwasowe 1-22 oraz 231-253). Podczas procesu tzw. dojrzewania białka sekwencje te ulegaja odcięciu. N-końcowy peptyd sygnałowy odcinany jest podczas transportu cząsteczki PrP do wnętrza siateczki endoplazmatycznej (ER), zaś odcięcie peptydu C-końcowego zwiazane jest $z$ dołaczeniem grupy glikozylofosfatydyloinozytolowej (GPI), za pomoca której białko kotwiczone

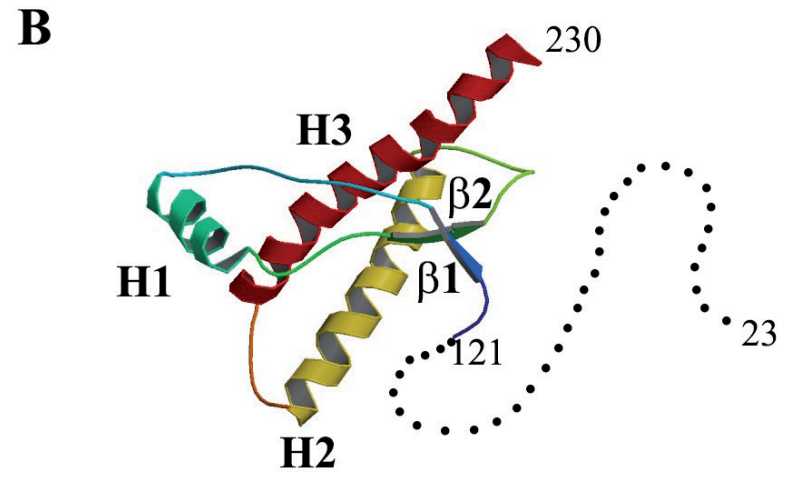

Ryc. 2. Budowa PrP.

(A) Schemat przedstawiający cząsteczkę PrP człowieka. Na schemacie zaznaczono: (SP) - peptydy sygnałowe, (OR) - ośmio-aminokwasowe powtórzone sekwencje, (TM) - domenę transbłonowa, (NLS) - sekwencje sygnałowe lokalizacji jądrowej, (S-S) - mostek dwusiarczkowy, (GPI) - miejsce dołączenia kotwicy glikozylofosfatydyloinozytolowej, (Asn181 i Asn179) - reszty asparaginy ulegajace glikozylacji oraz struktury drugorzędowe: helisy a oraz struktury $\beta$. Strzałkami zaznaczono miejsca, w których dochodzi do proteolitycznego cięcia białka prowadzącego do powstania fragmentów N1 i N2. (B) Model struktury przestrzennej cząsteczki PrP człowieka. Na rycinie zaznaczono struktury a-helikalne: H1, H2 i H3 oraz struktury $\beta$. Linia przerywana zaznaczono N-końcowy nieustrukturyzowany fragment, niewidoczny w strukturze krystalograficznej (wg PDB 10.2210/pdb1QLX/ pdb, ZAHN i współaut. 2000, zmodyfikowana).

jest w błonie komórkowej (BASLER i współaut. 1986, STAHL i współaut. 1987, TURK i współaut. 1988). Dojrzałe białko prionowe człowieka zbudowane jest z 208 reszt aminokwasowych i posiada mase cząsteczkowa około $23 \mathrm{kDa}$ (AGUZZI i współaut. 2008). Białko PrP ulega również innym modyfikacjom potranslacyjnym, takim jak: N-glikozylacja reszt asparaginy Asn181 i/lub Asn197, utworzenie mostka dwusiarczkowego między resztami Cys179 i Cys214 oraz proteolitycznej obróbce cząsteczki (PRUSINER 1998). W mózgach zdrowych organizmów w wyniku ograniczonej proteolizy $\mathrm{w}$ obrębie reszt 110-112 czasteczki PrP, powstaja fragmenty oznaczane jako N1 oraz C1 (CHEN i współaut. 1995). Z kolei w mózgach organizmów 

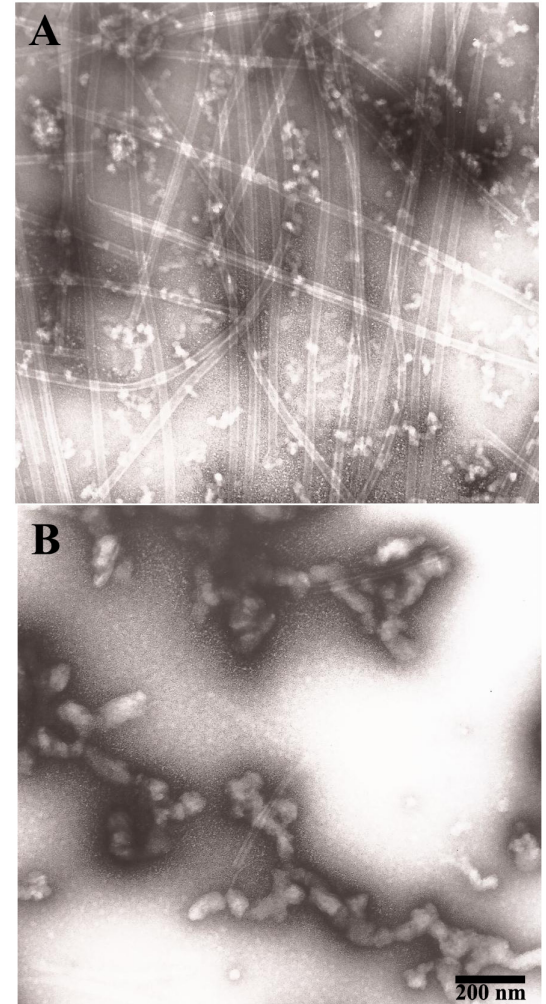

Ryc. 3. Mikrofotografie przedstawiajace struktury tubuliny powstajace pod wpływem PrP w warunkach sprzyjajacych tworzeniu mikrotubul (NIEZNANSKI i współaut. 2006), uzyskane za pomoca transmisyjnej mikroskopii elektronowej.

(A) Preparaty tubuliny inkubowanej w nieobecności i (B) w obecności PrP (zdjęcia niepublikowane).

cierpiacych na choroby prionowe dochodzi do proteolitycznego cięcia $\mathrm{w}$ obrębie reszty 90, a powstajace fragmenty nazywane sa: N2 oraz C2 (CHEN i współaut. 1995). Czasteczka PrP składa się $z$ dwóch głównych regionów. Pierwszy jest nieustrukturyzowany i obejmuje reszty 23 125 (RIEK i współaut. 1997). Region ten zawiera dwa ciagi zasadowych reszt (23-27 oraz 101-110). Sekwencje te pokrywają się $z$ regionami stanowiącymi sygnał lokalizacji jądrowej $\operatorname{PrP}$ (ang. nuclear localization signals, NLS; reszty 23-28 i 95-110) (Gu i współaut. 2003). W regionie N-końcowym zlokalizowane sa także wielokrotnie powtórzone sekwencje złożone $z$ ośmiu reszt aminokwasowych, (ang. octarepeats, OR; reszty: 50-91), które w czasteczce PrP stanowia główne miejsce wiązania jonów miedzi (HORNSHAW i współaut. 1995). Drugi region czasteczki, to domena globularna obejmujaca reszty 126-230. Domena ta utworzona jest przez trzy a-helisy oraz dwie krótkie struktury $\beta$, a stabilizowana jest przez pojedynczy mostek dwusiarczkowy (RIEK i współaut. 1997). W cząsteczce PrP można wyróżnić także region hydrofobowy, który może pełnić funkcję domeny transbłonowej (reszty 113-135) (LOPEZ i współaut. 1990)

W tkankach zdrowych organizmów PrP występuje głównie zewnątrzkomórkowo, w formie zakotwiczonej na powierzchni błony komórkowej, w obrębie struktur zwanych tratwami (ang. rafts) (TAYLOR i HOOPER 2006) i jest oznaczane jako $\operatorname{PrP}^{\mathrm{C}}$. Patologicznym konformerem białka prionowego, zwiazanym $z$ chorobami prionowymi jest PrP ${ }^{\mathrm{TSE}}$ (od ang. transmissible spongiform encephalopathy) lub $\mathrm{PrP}^{\mathrm{Sc}}$ (od ang. scrapie; gabczastej encefalopatii występującej u owiec). Uważa się, że konwersja $\operatorname{PrP}^{\mathrm{C}}$ do $\operatorname{PrP}^{\mathrm{TSE}}$ jest kluczowym procesem prowadzacym do rozwoju chorób prionowych (PRUSINER 1998). W procesie tym dochodzi do zwiększenia zawartości struktury $\beta$ i zmniejszenia zawartości struktury a $\mathrm{w}$ cząsteczce białka prionowego, co prowadzi do agregacji patogennego konformeru $\mathrm{w}$ postaci uporzadkowanych struktur zwanych amyloidami (PRUSINER 1998). Jednak mechanizm konwersji, jak i czynnik neurotoksyczny odpowiedzialny za rozwój TSE nie zostały jak dotad scharakteryzowane. Poza zewnatrzkomórkowym $\mathrm{PrP}^{\mathrm{C}}$, w zdrowych organizmach opisano również wewnatrzkomórkowo zlokalizowane białko prionowe, tzw. cytoplazmatyczne PrP (cytoPrP). Występuje ono np. w niektórych subpopulacjach neuronów hipokampa, wzgórza i kory nowej (MIRONOV i współaut. 2003). Tym niemniej cytoPrP uważane jest również za formę patologiczną. Ponadto, znane sa błonowe formy białka prionowego: ${ }^{\mathrm{N} m \mathrm{PrP}}$ oraz ${ }^{\mathrm{Ctm}} \mathrm{PrP}$ (YOST i współmat. 1990, HEGDE i współaut. 1998, KIM i współaut. 2001, KIM i HEGDE 2002). Te patologiczne formy usytuowane sa $\mathrm{w}$ błonie siateczki endoplazmatycznej za pomoca domeny hydrofobowej z C-końcowym (forma ${ }^{\mathrm{N} t m} \mathrm{PrP}$ ) lub N-końcowym (forma ${ }^{\mathrm{C} m} \mathrm{PrP}$ ) regionem eksponowanym na cytoplazmę. Podczas gdy forma NtmPrP opisywana była jak dotad jedynie in vitro, forma ${ }^{\mathrm{Ctm} P r P}$ występuje również in vivo, a jej stężenie $\mathrm{w}$ mózgach organizmów chorych na TSE wzrasta nawet do 30\% całkowitego białka prionowego. Do wzrostu stężenia tej transbłonowej formy PrP prowadza mutacje w obrębie domeny hydrofobowej, zwiazane $\mathrm{z}$ chorobami prionowymi np. występujaca w GSS (choroba Gerstmanna-Strausslera-Scheinkera) mutacja Pro105Leu czy Ala117Val (HEGDE i współaut. 1998, KIM i HEGDE 2002). Do wzrostu poziomu cytoplazmatycznej formy PrP, niezwiazanej $z$ błona ER, dochodzi w przypadku innych mutacji wykrywanych w GSS, Trp145Stop i Gln160Stop. Powstaje wówczas skrócona forma PrP pozbawiona C-końcowej domeny (ZANUSSO i współaut. 1999, HESKE i współaut. 2004). 
W tych przypadkach obserwowana jest obniżona translokacja PrP do ER i akumulacja PrP w cytoplazmie lub w jądrze komórkowym (ZANUSSO i współaut. 1999, MIESBAUER i współaut. 2010). Inną przyczyną wzrostu stężenia PrP we wnętrzu komórki może być transport zwrotny $z$ ER, jak zostało to opisane dla mutacji Asp177Asn, powiazanej ze śmiertelna rodzinna bezsennościa (ang. fatal familial insomnia, FFI) oraz rodzinna postacia choroby Creutzfeldta-Jakoba (ang. Creutzfeldt-Jakob disease, CJD) (MA i LINDQUIST 2001). Zaburzenia w translokacji PrP moga być również zwiazane ze stresem ER (ORSI i współaut. 2006). PrP gromadzace się w cytoplazmie ulega zazwyczaj szybkiej ubikwitynacji i proteasomalnej degradacji (YEDIDIA i współaut. 2001). Stąd zaburzenia aktywności proteasomu moga prowadzić do wzrostu stężenia cytoplazmatycznej formy PrP. Takie zjawisko obserwujemy w chorobach prionowych, gdzie patologiczna forma $\mathrm{PrP}^{\mathrm{Sc}}$, hamując bezpośrednio aktywność proteasomu, w konsekwencji prowadzi do wzrostu stężenia cytoPrP (MA i LindQuist 2001, MANGE i współaut. 2004). Nadprodukcja cytoplazmatycznej formy PrP jest obserwowana nie tylko w rodzinnych postaciach chorób prionowych, ale także w licznych doświadczalnych modelach TSE (CHAKRABARTi i współaut. 2009, Miesbauer i współaut. 2010).

Szereg badań wskazuje, że cytoPrP może być białkiem neurotoksycznym (MA i współaut. 2002, GRENIER i współaut. 2006, WANG i współaut. 2009), chociaż molekularny mechanizm toksyczności tej formy białka prionowego nie został jak dotąd w pełni poznany. Oddziaływanie cytoPrP $z$ niektórymi cytoplazmatycznymi białkami jak np.: Bcl-2 (ang. B-cell lymphoma 2 protein), Mgrn (ang. mahogunin) czy NRAGE (ang. neurotrophin receptor-interacting MAGE homolog), prowadzi do ich agregacji i utraty fizjologicznych funkcji tych białek (BRAGASON i PALSDOTTIR 2005, RAMBOLD i współauat. 2006, CHAKRABARTI i HEGDE 2009). Co ciekawe, do białek, które moga oddziaływać $z$ nieprawidłowo zlokalizowanym PrP, należy tubulina, a konsekwencja tego oddziaływania jest hamowanie formowania MT (NIEZNANSKI i współaut. 2005). Sądzimy więc, że nieprawidłowa lokalizacja PrP, umożliwiajaca oddziaływanie cytoPrP $z$ białkami, które nie sa jego fizjologicznymi partnerami, może leżeć u podstawy neurotoksyczności tej formy białka prionowego w TSE (MIESBAUER i współaut. 2010, NIEZNANSKI 2010, ZAJKOWSKI i współaut. 2015).

\section{ODDZIALYWANIE PrP Z TUBULINA}

Pierwsze badania wskazujące na oddziaływanie białka prionowego $z$ tubulina zosta- ły przeprowadzone przez BROwNA i współaut. (1998). Z badań tych wynikało, że syntetyczny peptyd odpowiadajacy sekwencji 106126 białka prionowego (PrP 106-126), wiąże się $z$-a, jak i $\beta$-tubuliną $z$ ekstraktów mózgu. Peptyd ten hamował proces formowania mikrotubul, a wprowadzenie mutacji Ala117Val, zwiazzanej $z$ GSS, prowadziło do jeszcze silniejszego hamowania polimeryzacji tubuliny (BROWN 2000). Efekt ten obserwowano jednak wyłacznie w obecności białka Tau, co mogło wskazywać, iż peptyd PrP 106-126 asocjuje $z$ tubulina za pośrednictwem tego właśnie białka. W kolejnych badaniach pokazano, że pełnej długości PrP ulega koimmunoprecypitacji $Z$ tubulina (KESHET i współaut. 2000). Zauważono również kolokalizację N-końcowego fragmentu $\operatorname{PrP} z$ mikrotubulami w hodowlach komórek neuroblastomy N2a (linia wyprowadzona $z$ nerwiaka zarodkowego myszy) transfekowanych konstruktami GFP-PrP, jak i jego koimmunoprecypitacje $\mathrm{z}$ tubulina $\mathrm{w}$ lizatach $\mathrm{z}$ tych komórek (HACHIYA i współaut. 2004a). Autorzy zidentyfikowali reszty 1-91 cząsteczki PrP jako odpowiedzialne za tę kolokalizację. Badania te pozwoliły wówczas na wyciagniecie wniosku, że PrP i tubulina moga asocjować ze sobą za pośrednictwem innych cząsteczek. Ponadto pokazano, że transport wewnątrzkomórkowy konstruktów GFP-PrP jest zależny od mikrotubul i odbywa się $z$ udziałem motorów molekularnych $z$ rodziny dynein i kinezyn (HACHIYA i współaut. 2004b) oraz związany jest $z$ obecnościa dwóch sekwencji w czasteczce PrP: reszt 23-33 oraz 53-91. Podobne obserwacje potwierdziły też inne badania, przeprowadzone na komórkach N2a, z których wynikało, że również transport $\mathrm{PrPS}^{\mathrm{Sc}}$ do jądra komórkowego zachodzi tylko wówczas, gdy komórki posiadaja nienaruszony cytoszkielet mikrotubularny (MANGE i współaut. 2004). Dowodów na bezpośrednie oddziaływanie białka prionowego $z$ tubulina dostarczyły dopiero nasze badania $z$ wykorzystaniem metody kosedymentacji oczyszczonych białek oraz ich kowalencyjnego sprzęgania $z$ użyciem EDC [1-etylo-3-(3dimetyloaminopropylo)karbodiimid], czynnika sieciujacego o tzw. zerowej długości (NIEZNANSKI i współaut. 2005). Badanie te wykazały, że pełnej długości $\operatorname{PrP}^{\mathrm{C}} \mathrm{z}$ ekstraktów $z$ mózgu świni oddziałuje $z$ oczyszczona tubulina. Produktu sieciowania nie obserwowano dla PrP C1, czyli fragmentu pozbawionego końca N. Ponadto, oczyszczone rekombinowane białko prionowe (rPrP) również wiązało się do wyizolowanej tubuliny. Ciekawa obserwacja było to, że $\operatorname{PrP}^{\mathrm{C}} z$ mózgu świni współoczyszcza się $z$ tubuliną, co może stanowić kolejny dowód na silne oddziaływanie tych białek ze sobą. 
Istotna konsekwencją bezpośredniego oddziaływania białka prionowego $z$ tubulina jest jego wpływ na polimeryzacje tubuliny (NieZNANSKI i współaut. 2006). Z badań wykorzystujących pomiar rozproszenia światła (ang. light scattering), metodę standardowo stosowana do monitorowania tempa polimeryzacji tubuliny oraz transmisyjna mikroskopię elektronowa (ang. transmission electron microscopy, TEM) wynika, że PrP hamuje polimeryzację tubuliny prowadzac do jej oligomeryzacji, a następnie agregacji. Tak zagregowana tubulina nie jest zdolna do formowania mikrotubul (Ryc. 3). Wykorzystanie, w naszych badaniach, mutantów delecyjnych PrP pozwoliło na zidentyfikowanie dodatnio naładowanego fragmentu 2332, jako głównego miejsca oddziaływania $z$ tubulina (OSIECKA i współaut. 2009). Z kolei zastosowanie ograniczonej proteolizy a- i $\beta$-tubuliny za pomoca trypsyny, chymotrypsyny oraz subtylizyny pozwoliło na identyfikacje fragmentów a-tubuliny odpowiadajacych resztom aminokwasowym 339-438 i $\beta$-tubuliny 281-433, jako potencjalnych miejsc oddziaływania $z$ PrP. Przeprowadzone badania wykazały, że peptyd PrP 23-32 wiaże się $\mathrm{z}$ tubulina $\mathrm{i}$ wywołuje jej oligomeryzacje, co prowadzi do hamowania tworzenia mikrotubul. Zastosowanie peptydu PrP 1-30, posiadajacego dodatkowo sekwencję sygnałowa 1-22, która umożliwia mu penetrację poprzez błonę komórkową (LUNDBERG i współaut. 2002), prowadzi do rozpadu cytoszkieletu mikrotubularnego komórek nabłonkowych linii HEp-2 (OsIECKA i współaut. 2009). Obserwacja ta została później potwierdzona na komórkach HeLa, transfekowanych plazmidem kodujacym cytoPrP (PrP 23-231) (Li i współaut. 2011). Bardzo ciekawa obserwacja jest to, że zmiany indukowane przez peptyd PrP 1-30 sa hamowane w komórkach HEp-2 transfekowanych plazmidem kodujaccym białko Tau (OsIECKA i współaut. 2011). Badania na wyizolowanych białkach potwierdzily, że zarówno frakcja białek MAP, jak i Tau hamuje indukowana przez PrP agregację tubuliny. $Z$ kolei fosforylacja białka Tau prowadzi do utraty tej protekcyjnej zdolności (OSIECKA i współaut. 2011). Ponadto, w badaniach na komórkach neurosekrecyjnych PC12 (linia wyprowadzona ze szczurzych komórek guza chromochłonnego rdzenia nadnerczy), peptyd 1-30 prowadził do formowania nieprawidłowych wrzecion podziałowych. W badaniach $z$ wykorzystaniem doświadczeń kosedymentacyjnych oraz testu ruchliwości (ang. motility assay) okazało się, że PrP osłabia przyłączanie kinezyny Ncd (ang. non-claret disjunctional) do mikrotubul i w ten sposób hamuje zależny od niej transport po mikrotubulach. Ponadto, $z$ doświadczeń kosedymentacyj- nych wynikało, że PrP nie konkuruje z Tau o miejsce wiazania na MT, a zatem obserwowane efekty można tłumaczyć zmianami w strukturze mikrotubul spowodowanymi bezpośrednim oddziaływaniem PrP-tubulina (NIEZNANSKA i współaut. 2012). Ponieważ Ncd jest motorem molekularnym odpowiedzialnym za prawidłową organizację wrzeciona podziałowego, można przypuszczać, że wyżej opisane formowanie nieprawidłowych wrzecion może być zwiąane $z$ zaburzeniem funkcji kinezyn. W badaniach przeprowadzonych na komórkach PC12, poddanych działaniu czynnika wzrostu neuronów NGF (ang. nerve growth factor), pod wpływem którego komórki zmieniaja się fenotypowo $\mathrm{z}$ neurosekrecyjnych na komórki wysuwające wypustki podobne do neurytów neuronów ośrodkowego układu nerwowego wykazano, że peptyd PrP 1-30 prowadzi do rozpadu cytoszkieletu mikrotubularnego i zaniku tych cytoplazmatycznych wypustek. Co istotne, nasze badania przeprowadzone na hodowlach neuronów pierwotnych szczura pokazały, że peptyd PrP 1-30 dodany do hodowli prowadzi do rozpadu cytoszkieletu mikrotubularnego, zaniku neurytów, a ostatecznie do śmierci nekrotycznej komórek nerwowych (ZAJKOWSKI i współaut. 2015). Zaobserwowano również zmniejszenie liczby kolców dendrytycznych na neuronach traktowanych $\operatorname{PrP}$ 1-30. Ponieważ kolce sa strukturami tworzacymi postsynaptyczna część synaps pobudzających (KASAI i współaut. 2003), uważa się, że zmiany $\mathrm{w}$ gęstości, jak i morfologii kolców zwiazane sa ściśle $z$ plastycznością synaptyczna (KASAI i współaut. 2010). Co ciekawe, zmniejszenie gęstości kolców dendrytycznych obserwowano u zwierzat zakażonych TSE (JOHNSTON i współaut. 1997, BROWN i współaut. 2001). Wiadomo, że oprócz aktyny, istotna rolę $\mathrm{w}$ morfologii kolców odgrywa tubulina (DENT 2017). Zatem, wpływajac na transport mikrotubularny oraz stabilność cytoszkieletu mikrotubularnego można się spodziewać zmian w stabilności i morfologii kolców, co w konsekwencji może prowadzić do zaburzeń $\mathrm{w}$ prawidłowym funkcjonowaniu synaps. Wykazano również, że zastosowanie czynnika stabilizujacego MT, jakim jest taksol, który wiąże się $\mathrm{z}$ mikrotubulami i w sposób nieodwracalny stabilizuje ich strukturę (SCHIFF i wspólaut. 1997), prowadziło do ochrony komórek nerwowych przed szkodliwym działaniem PrP 1-30 (ZAJKOWSKI i współaut. 2015). Co ciekawe, podobny efekt zaobserwowano stosując inhibitory kinazy białkowej GSK-3, która, jak już wcześniej wspomniano, odpowiada za fosforylacje białek MAP. Obniżenie poziomu ufosforylowania Tau i MAP 2 przez zastosowanie LiCl, niespecyficznego inhibitora kinazy GSK-3 (FoR- 


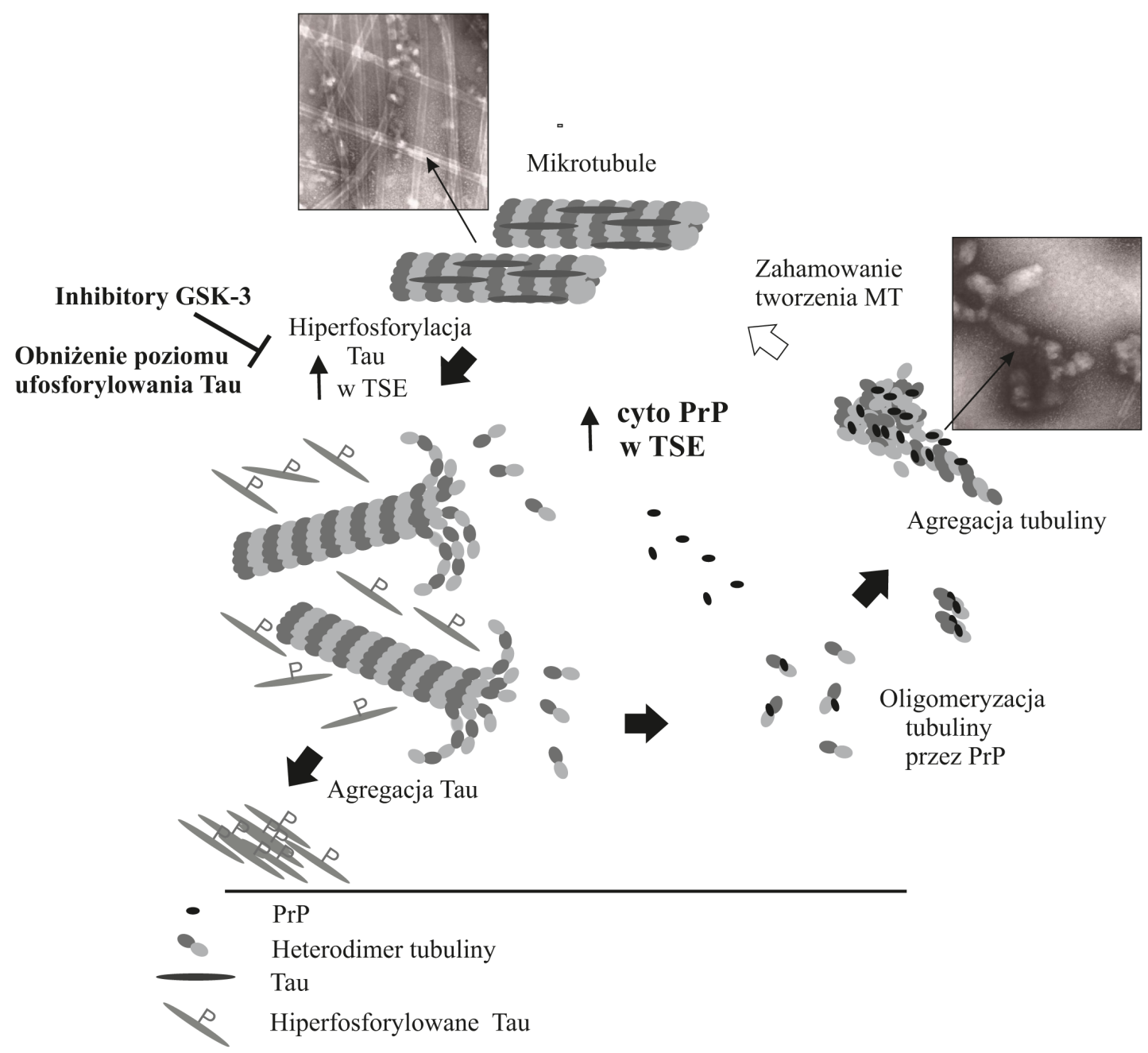

Ryc. 4. Schemat przedstawiajacy hipotetyczny mechanizm działania cytoPrP na cytoszkielet mikrotubularny.

Wzrost poziomu ufosforylowania Tau, obserwowany w TSE, prowadzi do destabilizacji mikrotubul (ufosforylowane Tau dysocjuje od MT). Tubulina pozbawiona stabilizującego wpływu Tau może ulegać oligomeryzacji/agregacji przez cytoPrP, którego podwyższone stężenie obserwowane jest w TSE. Koagregacja cytoPrP i tubuliny prowadzi do zahamowania tworzenia MT. Obniżenie poziomu ufosforylowania Tau, przez zastosowanie inhibitorów kinazy GSK-3 prowadzi do stabilizacji MT i ochrony przed toksycznym działaniem cytoPrP (wg OsIEcKA i współaut. 2011, zmodyfikowana).

LENZA i współaut. 2014) oraz CHIR98014, specyficznego inhibitora tej kinazy (RING i współaut. 2003), chroniło neurony przed wyżej opisaną cytotoksycznością wywołaną przez PrP 1-30 (ZAJKOWSKI i współaut. 2015).

Przedstawione obserwacje wskazuja jednoznacznie, że cytoPrP może być forma neurotoksyczna białka prionowego, a toksyczność jest zwiazana $z$ jego bezpośrednim oddziaływaniem $z$ tubulina, prowadzacym do rozpadu cytoszkieletu mikrotubularnego. Obniżenie poziomu ufosforylowania klasycznych MAP i stabilizowanie $w$ ten sposób MT, chroni komórki nerwowe przed destrukcyjnym działaniem cytoplazmatycznej formy PrP i może stanowić potencjalny kierunek w terapii niektórych chorób prionowych (Ryc. 4).

\section{Streszczenie}

Nieprawidłowo sfałdowane białko prionowe ( $\left.\mathrm{PrP}^{\mathrm{TSE}}\right)$ uważane jest za główny czynnik prowadzacy do rozwoju zakaźnych chorób neurodegeneracyjnych, zwanych pasażowalnymi encefalopatiami gąbczastymi (TSE). Mechanizm konwersji fizjologicznej formy białka prionowego $\operatorname{PrP}^{\mathrm{C}}$ do patologicznej $\mathrm{PrP}^{\mathrm{TSE}}$, jak i forma neurotoksyczna tego białka, nie zostały jak dotąd w pełni scharakteryzowane. W warunkach fizjologicznych $\mathrm{PrP}^{\mathrm{C}}$ występuje głównie zewnątrzkomórkowo, gdzie przyczepione jest za pomoca kotwicy GPI do powierzchni błony komórkowej. Znane sa jednak, również zlokalizowane w cytoplazmie formy PrP, zwane cytoPrP. Co ciekawe, stężenie cytoPrP znaczaco wzrasta w TSE. Badania ostatnich lat dowo- 
dzą, że nieprawidłowo zlokalizowane w cytoplazmie PrP może być czynnikiem neurotoksycznym, a mechanizm neurotoksyczności związany jest prawdopodobnie $z$ bezpośrednim oddziaływaniem tej formy białka prionowego $z$ tubulina. Oddziaływanie to prowadzi do agregacji tubuliny, zahamowania formowania MT, rozpadu cytoszkieletu mikrotubularnego i w konsekwencji śmierci komórki. Stabilizacja MT, np. przez obniżenie poziomu ufosforylowania zwiazanych $z$ mikrotubulami białek MAP chroni neurony przed toksycznością cytoplazmatycznej formy $\operatorname{PrP}$.

\section{LITERATURA}

Aguzzi A., Baumann F., Bremer J., 2008. The prion's elusive reason for being. Annu. Rev. Neurosci. 31, 439-477.

AKHMANOVA A., ŚTEINMETZ M. O., 2008. Tracking the ends: a dynamic protein network controls the fate of microtubule tips. Nat. Rev. Mol. Cell Biol. 9, 309-322.

Al-Bassam J., Ozer R. S., SAFer D., Halpain S., MilligAN R. A., 2002. MAP2 andtau bind longitudinally along the outer ridges of microtubule pro-tofilaments. J. Cell Biol. 157, 1187 1196.

Basler K., Oesch B., Scott M., Westaway D., WÄLCHLI M., GROTH D. F., MCKINLEY M. P., PRUSINER S. B., WEISSMANN C., 1986. Scrapie and cellular $\operatorname{PrP}$ isoforms are encoded by the same chromosomal gene. Cell 46, 417-428.

BAUTISTA M. J., GuTIERREZ J., SAlguero F. J., FERNANDEZ DE MARCo M. M., ROMERO-TREVEJO J. L., Gomez-Villamandos J. C., 2006. BSE infection in bovine PrP transgenic mice leads to hyperphosphorylation of tau-protein. Vet. Microbiol. 115, 293-301.

BENDHEIM P. E., BROWN H. R., Rudelli R. D., ScAla L. J., GOLleR N. L., WEN G. Y., KASCSAK R. J., CASHMAN N. R., BOLTON D. C., 1992. Nearly ubiquitous tissue distribution of the scrapie agent precursor protein. Neurology 42, 149-156.

Biernat J., Gustke N., Drewes G., Mandelkow E. M., MANDELKOW E., 1993. Phosphorylation of Ser262 strongly reduces binding of tau to microtubules: distinction between PHF-like immunoreactivity and microtubule binding. Neuron 11, 153-163.

BRAGASON B. T., PALSDOTTIR A., 2005. Interaction of $\operatorname{Pr} P$ with NRAGE, a protein involved in neuronal apoptosis. Mol. Cell. Neurosci. 29, 232244.

Bramblett G. T., Goedert M., JAKes R., Merrick S. E., TROJANOWSKI J. Q., LEE V. M., 1993. Abnormal tau phosphorylation at Ser396 in Alzheimer's disease recapitulates development and contributes to reduced microtubule binding. Neuron 10, 1089-1099.

Breuss M. W., LeCA I., GSTREIN T., HANSEN A. H., KEAYS D. A., 2017. Tubulins and brain development - The origins of functional specification. Mol. Cell. Neurosci., doi: 10.1016/j. mcn.2017.03.002.

BRown D., BELICHENKO P., SAlEs J., JeFFrey M. FRASER J. R., 2001. Early loss of dendritic spines in murine scrapie revealed by confocal analysis. Neuroreport 12, 179-183.

BROWN D. R., 2000. Altered toxicity of the prion protein peptide PrP106-126 carrying the Ala(117)-->Val mutation. Biochem. J. 346, 785791.

BROWN D. R., SCHMIDT B., KRETZSCHMAR H. A., 1998. Prion protein fragment interacts with
PrP-deficient cells. J. Neurosci. Res. 52, 260267.

Cassimeris L., SpitTle C., 2001. Regulation of microtubule-associated proteins. Int. Rev. Cytol. 210, 163-226.

Chakrabarti O., AshoK A., Hegde R. S., 2009. Prion protein biosynthesis and its emerging role in neurodegeneration. Trends. Biochem. Sci. 34, 287-295.

ChaKrabarti O., Hegde R. S., 2009. Functional depletion of mahogunin by cytosolically exposed prion protein contributes to neurodegeneration. Cell 137, 1136-1147.

Chen S. G., Teplow D. B., PARChi P., Teller J. K., Gambetti P., Autilio-GambetTi L., 1995. Truncated forms of the human prion protein in normal brain and in prion diseases. J. Biol. Chem. 270, 19173-19180.

Cross D., Dominguez J., Maccioni R. B., Avila J., 1991. MAP-1 and MAP-2 binding sites at the C-terminus of beta-tubulin. Studies with syn-thetic tubulin peptides. Biochemistry 30, 4362-4366.

DENT E. W., 2017. Of microtubules and memory: implications for microtubule dynamics indendrites and spines. Mol. Biol. Cell. 28, 1-8.

Downing K. H, NoGales E., 1998. New insights into microtubule structure and function from the atomic model of tubulin. Eur. Biophys. J. 27, 431-436.

DRECHSEl D. N, HyMAN A. A, COBB M. H, KIRSCHNER M. W., 1992. Modulation of the dynamic instability of tubulin assembly by the microtubule-associated protein tau. Mol. Biol. Cell 3, 1141-1154.

Forlenza O. V., DE-Paula V. J., Diniz B. S., 2014. Neuroprotective effects of lithium: implications for the treatment of Alzheimer's disease and related neurodegenerative disorders. ACS Chem. Neurosc. 5, 443-450.

Grenier C., BissonnetTe C., VOlKov L., Roucou X., 2006. Molecular morphology and toxicity of cytoplasmic prion protein aggregates in neuronal and non-neuronal cells. J. Neurochem. 97, 1456-1466.

Gu Y., HiNNERWISCH J., FREdRICKS R., KALEPU S., MisHRA R. S., SingH N., 2003. Identification of cryptic nuclear localization signals in the prion protein. Neurobiol. Dis. 12, 133-149.

HaChIYA N. S., WATANABE K., SAKASEGaWA Y., KANEKO K., 2004a. Microtubulesassociated intracellular localization of the NH2-terminal cellular prion protein fragment. Biochem. Biophys. Res. Commun. 313, 818-823.

HachiYa N. S., WATANABE K., YAMADA M., SAKaseGAWA Y., KANEKO K., 2004b. Anterograde and retrograde intracellular trafficking of fluorescent cellular prionprotein. Biochem. Biophys. Res. Commun. 315, 802-807.

Hawkins T., MiRIGian M., SElcuk Yasar M., Ross J. L., 2010. Mechanics of microtubules. J. Biomech. 43, 23-30.

Hegde R. S., Mastrianni J. A., ScotT M. R., DeFEA K. A., TREMBLAY P., TORCHIA M., DEARMOND S. J., PRUSINER S. B., LINGAPPA V. R. A., 1998. A transmembrane form of the prion protein in neurodegenerative disease. Science 279, 827-834.

Heske J., Heller U., Winklhofer K. F., TAtZelt J., 2004. The C-terminal globular domain of the prion protein is necessary and sufficient for import into the endoplasmic reticulum. J. Biol. Chem. 279, 5435-5443.

HORNSHAW M. P., MCDERMOTT J. R., CANDY J. M., 1995. Copper binding to the $N$-terminal tandem repeat regions of mammalian and avian 
prion protein. Biochem. Biophys. Res. Commun. 207, 621-629.

JANKE C., 2014. The tubulin code: molecular components, readout mechanisms, and functions. J. Cell Biol. 18, 461-472.

JOHNSTON A. R., BLACK C., Fraser J., MACLEOD N., 1997. Scrapie infection alters the membrane and synaptic properties of mouse hippocampal CA1 pyramidal neurones. J. Physiol. $500,1-15$.

Jourdain L., Curmi P., Sobel A., Pantaloni D., CARLIER M. F., 1997. Stathmin: a tubulin-sequestering protein which forms a ternary T2S complex with two tubulin molecules. Biochemistry 36, 10817-10821.

Kasai H., MatsuzaKi M., NOGUChI J., Yasumatsu N., NAKAHARA H., 2003. Structurestability-function relationships of dendritic spines. Trends Neurosci. 26, 360-368.

Kasai H., FuKUda M., Watanabe S., Hayashi-TakaGI A., NoGuchI J., 2010. Structural dynamics of dendritic spines in memory and cognition. Trends. Neurosci. 33, 121-129.

Keshet G. I., BAR-Peled O., Yaffe D., Nudel U., GABIZON R., 2000. The cellular prion protein colocalizes with the dystroglycan complex in the brain. J. Neurochem. 75, 1889-1897.

KIM S. J., HEGDE R. S., 2002. Cotranslational partitioning of nascent prion protein into multiple populations at the translocation channel. Mol. Biol. Cell 13, 3775-3786.

Kim S. J., RahbaR R., Hegde R. S., 2001. Combinatorial control of prion protein biogenesis by the signal sequence and transmembrane domain. J. Biol. Chem. 276, 26132-26140.

Li X. L., WANG G. R., JiNG Y. Y., PAN M. M., DONG C. F., ZHOU R. M., WANG Z. Y., SHI Q., GaO C., Dong X. P., 2011. Cytosolic PrP induces apoptosis of cell by disrupting microtubule assembly. J. Mol. Neurosci. 43, 316-325.

Lopez C. D., Yost C. S., Prusiner S. B., Myers R. M., LingaPPA V. R., 1990. Unusual topogenic sequence directs prion protein biogenesis. Science 248, 226-229.

Lowe J., LI H., Downing K. H., Nogales E., 2001. Refined structure of alpha betatubulin at 3.5 A resolution. J. Mol. Biol. 313, 10451057.

LUDUEÑA R. F., 2013. A hypothesis on the origin and evolution of tubulin. Int. Rev. Cell Mol. Biol. 302, 41-185.

LundBerg P., Magzoub M., LindBerg M., HäLLBRINK M., JARVET J., ERIKSSON L. E., LANGEL U., GRÄSLUND A., 2002. Cell membrane translocation of the Nterminal (1-28) part of the prion protein. Biochem. Biophys. Res. Commun. 299, 85-90.

MA J., LiNDQUIST S., 2001. Wild-type $\operatorname{PrP}$ and a mutant associated with prion disease are subject to retrograde transport and proteasome degradation. Proc. Natl. Acad. Sci. USA 98, 14955-14960.

MA J., WollmanN R., LindQuist S., 2002. Neurotoxicity and neurodegeneration when $\operatorname{PrP}$ accumulates in the cytosol. Science 298, 17811785.

MACCIONI R. B., RIVAS C. I., VERA J. C., 1988. Differential interaction of syntheticpeptides from the carboxyl-terminal regulatory domain of tubuliny with microtubule-associated proteins. EMBO J. 7, 1957-1963.

Mange A., Crozet C., Lehmann S., Beranger F., 2004. Scrapie-like prion protein is translocated to the nuclei of infected cells independently of proteasome inhibition and interacts with chromatin. J. Cell Sci. 117, 2411-2416.
Melki R., KerJan P., Waller J. P., CARlier M. F., 1991. Pantaloni D. Interaction of microtubule-associated proteins with microtubules: yeast lysyl-and valyl-tRNA synthetases and tau 218-235 synthetic peptide asmodel systems. Biochemistry 30, 11536-11545.

Miesbauer M., RAmbOlD A. S., Winklhofer K. F., TATZELT J., 2010. Targeting of the prion protein to the cytosol: mechanisms and consequences. Curr. Issues. Mol. Biol. 12, 109118.

Mironov A. JR., LataWiEC D., Wille H., BouZAMONDO-BERNSTEIN E., LEgNAME G., Williamson R. A., BURTON D., DEARMOND S. J., PRUSINER S. B., PeTERS P. J., 2003. Cytosolic prion protein in neurons. J. Neurosci. 23, 7183-7193.

NIEZNANSKA H., DUDEK E., ZAJKOWSKI T., SZCZESNA E., KASPRZAK A. A., NieZNANSKI K., 2012. Prion protein impairs kinesin-driven transport. Biochem. Biophys. Res. Commun. 425, 788-793.

NIEZNANSKI K., 2010. Interactions of prion protein with intracellular proteins: so manypartners and no consequences? Cell. Mol. Neurobiol. 30, 5, 653-666.

NiEZNANSKI K., NiEZNANSKA H., SKOWRONEK K. J., Osiecka K. M., STEPKOWSKI D., 2005. Direct interaction between prion protein and tubulin. Biochem. Biophys. Res. Commun. 334, 403411.

Nieznanski K., Podlubnaya Z. A., Nieznanska H., 2006. Prion protein inhibits microtubule assembly by inducing tubulin oligomerization. Biochem. Biophys. Res. Commun. 349, 391399.

NoGALES E., 2000. Structural insights into microtubule function. Annu. Rev. Biochem. 69, 277302.

NoGales E., Wolf S. G., Downing K. H., 1998. Structure of the alpha beta tubulin dimer by electron crystallography. Nature 391, 199-203.

ORSI A., FIORITI L., CHIESA R., SITIA R., 2006. Conditions of endoplasmic reticulum stress favor the accumulation of cytosolic prion protein. J. Biol. Chem. 281, 41, 30431-30438.

OSIECKA K. M., NIEZNANSKA H., SKOWRONEK K. J., KAROLCZAK J., SCHNEIDER G., NIEZNANSKI K., 2009. Prion protein region 23-32 interacts with tubulin and inhibits microtubule assembly. Proteins 77, 279-296.

Osiecka K. M., NiEZNANSKa H., SKOWRONEK K. J., JOZWIAK J., NIEZNANSKI K., 2011. Tau inhibits tubulin oligomerization induced by prion protein. Biochim. Biophys. Acta 1813, 1845-1853.

Parker A. L., TeO W. S., McCarroll J. A., KAVALLARIS M., 2017. An Emerging Role for Tubulin Isotypes in Modulating Cancer Biology and Chemotherapy Resistance. Int. J. Mol. Sci.18, E1434.

Perez M., RoJo A. I., WANdosell F., DiAZ-Nido J., Avila J. 2003. Prion peptide induces neuronal cell death through a pathway involving glycogen synthase kinase 3. Bioch. J. 372, 129-136.

Premzl M., Gready J. E., Jermin L. S., Simonic T., Marshall Graves J. A., 2004. Evolution of vertebrate genes related to prion and Shadoo proteins-clues from comparative genomic analysis. Mol. Biol. Evol. 21, 2210-2231.

PRUSINER S. B., 1998. Prions. Proc. Natl. Acad. Sci. USA 95, 13363-13383.

RAMBOLD A. S., Miesbauer M., RAPAPORT D., BARTKE T., BAIER M., WinkLhOFER K. F., TATZELT J., 2006. Association of Bcl-2 with misfolded prion protein is linked to the toxic potential of cytosolic PrP. Mol. Biol. Cell 17, 8, 3356-3368. 
RIEK R., HoRNEMANN S., WIDER G., GLOCKSHUBER R., WÜTHRICH K., 1997. NMR characterization of the full-length recombinant murine prion protein, $m P r P(23-231)$. FEBS Lett. 413, 282288.

RAMKUMAR A., JONG B. Y., ORI-MCKenNEY K. M., 2017. ReMAPping the microtubule landscape: How phosphorylation dictates the activities of microtubule-associated proteins. Dev. Dyn., doi: $10.1002 /$ dvdy.24599.

Ring D. B., JOHNSON K. W., HENRIKSEN E. J., Nuss J. M., GOFF D., KinNiCK T. R., MA S. T., Reeder J. W., Samuels I., Slabiak T., WaGMAN A. S., HAMMOND M. E., HARRISON S. D., 2003. Selective glycogen synthase kinase 3 inhibitors potentiate insulin activation of glucose transport and utilization in vitro and in vivo. Diabetes 52, 588-595.

Rivera-Milla E., OidTMANN B., PANAGiotidis C. H., BAIER M., SKLAVIADIS T., HOFFMANN R., ZHOU Y., Solis G. P., Stuermer C. A., Málaga-TrilLO E., 2006. Disparate evolution of prion protein domains and the distinct origin of Doppeland prion-related loci revealed by fish-to-mammal comparisons. FASEB J. 20, 317-319.

SCHIFF P. B., FANT J., HORWITZ S. B., 1979. Promotion of microtubule assembly in vitro by taxol. Nature 277, 665-667.

Sikorska B., LiBERSKI P. P., SOBÓw T., BUdKA H., IRONSIDE J. W., 2009. Ultrastructural study of florid plaques in variant Creutzfeldt-Jakob disease: a comparison with amyloid plaques in kuru, sporadic Creutzfeldt-Jakob disease and Gerstmann-Sträussler-Scheinker disease. Neuropathol. Appl. Neurobiol. 35, 46-59.

SchOENFElD T. A., OBAR R. A., 1994. Diverse distribution and function of fibrous

microtubule-associated proteins in the nervous system. Int. Rev. Cytol. 151, 67-137.

STAHL N., BORChElT D. R., HSIAO K., PRUSINER S. B., 1987. Scrapie prion protein contains a phosphatidylinositol glycolipid. Cell 51, 229240 .

ŠImić G., BABIĆ LEKo M., Wray S., HARRINGTON C., DElalle I., JOVANOV-MiloŠEVIĆ N., BAŽADONA D., BuÉe L., De Silva R., Di Giovanni G.,
WISCHIK C., HoF P. R., 2016. Tau protein hyperphosphorylation and aggregation in Alzheimer's disease and other tauopathies, and possible neuroprotective strategies. Biomolecules $6,6$.

TAYLOR D. R., HOOPER N. M., 2006. The prion protein and lipid rafts. Mol. Memb. Biol. 23, 89-99.

TURK E., Teplow D. B., HoOd L. E., PRUSINER S. B.,1988. Purification and properties of the cellular and scrapie hamster prion proteins. Eur. J. Biochem. 176, 21-30.

WADE R. H., 2009. On and around microtubules: an overview. Mol. Biotechnol. 43, 177-191.

WANG X., BOWERS S. L., WANG F., PU X.-A. A., NELSON R. J., MA J., 2009. Cytoplasmic prion protein induces forebrain neurotoxicity. Biochim. Biophys. Acta. 1792, 6, 555-563.

WestermanN S., WeBer K., 2003. Post-translational modifications regulate microtubul function. Nat. Rev. Mo. Cell Biol., 4, 938-947.

ZAJKOWSKI T., NIEZNANSKA H., NIEZNANSKI K., 2015. Stabilization of microtubular cytoskeleton protects neurons from toxicity of N-terminal fragment of cytosolic prion protein. Biochim. Biophys. Acta 1853, 2228-2239.

Zanusso G., Petersen R. B., Jin T., Jing Y., KANOUSH R., FERRARI S., GAMBETTI P., SINGH N., 1999. Proteasomal degradation and $N$-terminal protease resistance of the codon 145 mutant prion protein. J. Biol. Chem. 274, 2339623404.

Zhang D., Rogers G. C., Buster D. W., Sharp D. J., 2007. Three microtubule severing enzymes contribute to the "Pacman-flux" machinery that moves chromosomes. J. Cell Biol. 177, 231-242.

Yost C. S., Lopez C. D., Prusiner S. B., Myers R. M., LingaPPA V. R., 1990. Non-hydrophobic extracytoplasmic determinant of stop transfer in the prion protein. Nature 343, 669-672.

YEDIDIA Y., HORONCHIK L., TZABAN S., YANAI A. TARABOULOS A., 2001 Proteasomes and ubiquitin are involved in the turnover of the wildtype prion protein. EMBO J. 20, 5383-5391.

KOSMOS Vol. 67, 1, 121-130, 2018

HANNA NIEZNAŃSKA

Department of Biochemistry, Nencki Institute of Experimental Biology PAS, 3 Pasteur Str., 02-973 Warsaw, E-mail: h.nieznanska@nencki.gov.pl

INTERACTION OF PRION PROTEIN WITH MICROTUBULES

Summary

Misfolded prion protein ( $\left.\mathrm{PrP}^{\mathrm{TSE}}\right)$ is known as a major agent leading to infectious neurodegenerative diseases, known as transmissible spongiform encephalopathies (TSE). The mechanism of conversion of the physiological form of prion protein $\left(\mathrm{PrP}^{\mathrm{C}}\right)$ into the pathological $\operatorname{PrP}^{\mathrm{TSE}}$ as well as the identity of neurotoxic form of this protein is not fully characterized. Under physiological conditions, $\operatorname{Pr}^{\mathrm{C}}$ one, is predominantly extracellular, tethered to the plasma membrane surface through the GPI anchor. However, cytosolic forms of PrP, termed as cytoPrP have also been found. Interestingly, a significant increase in the concentration of cytoPrP is observed in TSE. Recently, it was shown that mislocalized PrP can be a neurotoxic agent. The mechanism of neurotoxicity might be linked to the direct interaction of this form of $\operatorname{PrP}$ with tubulin. This interaction leads to tubulin aggregation, inhibition of microtubules (MT) assembly, disruption of microtubular cytoskeleton and eventually cell death. MT stabilization, by decreasing the level of MAP phosphorylation, can protect neurons from toxic effect of cytosolic forms of $\operatorname{PrP}$.

Key words: microtubules, prion diseases, prion protein, tubulin 